form one band); there is a very broad band behind the middle, with its posterior margin flexuous; and the apex is also dark blue, the upper margin of the blue colour flexuous; the apex is broadly truncated, the truncature flexuous, the outer angle with a small tooth. The underside is green, with the flanks of the prothorax, a spot or two on the sterna and epipleura, a band on the posterior coxæ, and a transverse band in the middle of each abdominal segment yellow. Prosternal process smooth.

Hab. Torres Straits, Murray Island, and Cornwallis Island. Two examples received from the Rev. J. S. Macfarlane.

\title{
Stigmodera viridicincta.
}

Stigmodera viridicincta, Waterhouse, Tr. Ent. Soc. 1874, p. 543.

Three examples of this species were received with the above described. They agree in general coloration with the "variety" which I described, having the sides of the thorax deep red; the elytra yellow, with the sides and apex red; but in addition to the green at the suture and extreme apex of the elytra there is a transverse spot across the suture rather behind the middle, one of the specimens having another green spot on the disk of the elytron, which is really only a disconnected part of the transverse spot or band across the suture. This last specimen has also the red at the sides of the thorax united by a red band near the base; so that the whole thorax is red, except a large spot in front and the extreme base, which are green.

\section{Stigmodera sexmaculata.}

Stigmodera sexmaculata, Saunders, Journ. Linn. Soc. ix. p. 465, pl. ix. fig. 13.

An example of this species just received has the elytra entirely deep yellow, except the apex, which is blue.

British Museum,

May 18th, 1881.

\section{XLIX.-Mr. Butler on Butterflies from Japan. By H. J. Elwes, F.L.S.}

ON my return from India my attention was called to a paper by Mr. Butler in the Ann. \& Mag. Nat. Hist., Feb. 1881, p. 132, which seems to call for some reply on my part.

In a paper on the genus Colias by me in Trans. Ent. Soc. for October 1880, p. 133, I criticised his determination of 


\section{Mr. H. J. Elwes on Butterfies from Japan.}

some specimens of this genus from Japan, which, though not then published, were indicated as distinct species in the BritishMuseum collection, and have since been described by him. Mr. Butler seems to think it great presumption on my part to criticise his determination of species, and hints that my rash enthusiasm to do some work in a branch of natural history which is comparatively new to me has led me to write in haste what I shall repent at leisure.

Now, though I readily agree with him that, in order to avoid controversy, it would be better that his species should be examined by an entomologist of longer experience than myself, I do not at all repent what I have written, though, in the matter of the Candahar Colias, I must apologize for having used the word described when I should have said admitted. The lapsus calami must have been apparent from my quoting the authorities for the names. The fact is that at the time my paper was read Mr. Butler's paper (see P.Z.S. 1880, p. 403) was not yet published, and I had only seen a proof of it; but this slip does not alter the case materially, as I hold that a naturalist who admits species without question that have been previously described by others as varieties or aberrations only, as in the case of $C$. sareptensis and $C$. pallida, is responsible for their specific value.

To show how far my views of this question coincide with those of other naturalists, I may cite one recent case in which Mr. Butler's work has been tested by others ; and here, at any rate, it cannot be said that it has been done by inexperienced or hasty workers. Messrs. Godman and Salvin, in 'Biologia Centrali-Americana' (see "Lepidoptera," p. 73), in dealing with those species of the genus Euptychia which occur within their limits, have carefully examined their unrivalled collection. The genus having been twice reviewed by $\mathrm{Mr}$. Butler (see P.Z.S. 1866, p. 459, and Journ. Linn. Soc. Zool. xiii. 1876, p. 116), must be considered as one in which his matured views as to specific distinction are shown; and what is the result? Why, that forty-six supposed species and two named varieties of Euptychia (for a few of which, however, Mr. Butler is only partly responsible, though he has adopted them) are reduced to thirty; and in the case of $E$. camerta, Cr, which had been divided into five species, the following remark is made :- "We find it quite impossible to follow Mr. Butler and others in their minute subdivision of this species." See further on, p. 85, with regard to E. polyphemus *. Many similar cases could no doubt be found if it

* "After a close examination we are unable to discover any differences by which to recognize Mr. Butler's three species as distinct from each other." 
were worth while to search for them; but I do not suppose that any thing I can say will have the slightest effect in modifying his views.

But I find that Mr. Butler can be very hard on others who do not happen to have the same opportunities as himself for special training and the same facilities for referring new and rare species to their correct genera.

I refer to his remarks in Ann. \& Mag. Nat. Hist., March 1881, pp. 229 and 237, on M. Oberthür's memoir on the Lepidoptera of Askold, where, after going through his species critically, and correcting the nomenclature of most of them (which corrections will no doubt soon receive further corrections at the hands of some one else), he says that "it is impossible to overestimate the injury through waste of time which is occasioned to workers by the publication of duplicate names for the same species."

In this remark I most heartily concur with him; and though I shall not attempt to defend M. Oberthür from the charge of adding new synonyms to the list, yet it is, at any rate, easy to tell at once, by the beautiful figures in his liberally distributed 'Etudes,' what are the species to which his names refer; whilst I defy any one, even when descriptions of over a page length are given, as in the case of Colias Elwesi, to tell with or without figures what such species as that and Colias pallens really are, unless they see the types.

Since writing my paper I have carefully examined the species in question at the British Museum, and see no reason to alter my opinions respecting them-though, in the case of C. subaurata, I think that the colour of the underside in selected specimens may be enough to distinguish them. I repeat that it is most unlikely that in such a genus-by which I mean a genus of which most of the species are very wide-ranging and very variable, developing, under different conditions of life and in different climates, numerous slight local varieties and possibly hybrids-it is most unlikely that four species of one group (namely the hyale group, which, in the whole of the Nearctic and Palæarctic regions, has only four or five distinct species, from my point of view) should exist in Japan alone, or rather in that small part of Japan from which Mr. Maries's collection came. I said collections generally, but find that Mr. Butler includes in his list of species in this one collection four Colice of this group. I fully allow that the climatic conditions of the various islands in Japan are varied and likely to develop numerous variations, as is abundantly proved by the plants of Japan; but this seems to make my case the stronger. 
It is no doubt very easy to get over the difficulty by saying that what I call varieties Mr. Butler calls distinct species, and in some cases, as I have heard, even distinct genera; but I affirm with confidence that if the butterflies of Europe were treated by Mr. Butler in the same way as the butterflies of Japan have been, the number of names, I will not say species, would be doubled, and perhaps trebled, supposing that he had a largeenough collection to work upon and no critics *.

If any one with a rich collection of European and NorthAsiatic butterflies will take the trouble to examine the genus Argynnis closely, and test the validity of such species as $A$ : vorax, Butl., A. paphioides, Butl., A. rabdia, A. pallescens, Butl., A. locuples, Butl., or to examine some of his new species of Japanese Papilio with a good series of specimens, I think it will be found that they do not bear the test much better than the Colize; and, considering that some of his Japanese species have been described from drawings, like Pararge echinoides, and others from single faded and worn specimens, like $C$. pallens, this is not surprising, though I believe there were sufficient specimens of the Argynnes.

It is quite possible, and even probable, that a more perfect knowledge of the distribution, seasonal forms, and metamorphoses of Japanese insects may prove the distinctness of some of these species; but I think it is better to wait till there are at least good reasons for describing them, than to run the risk of adding more to the already long list of useless and troublesome synonyms.

I will here take the opportunity of making remarks on some new species described by Mr. Butler in Ann. \& Mag. Nat. Hist., Jan. 1881, p. 32.

Argynnis gemmata, Butl., is a very distinct and beautiful species-so much so, that I was astonished to find, when I compared my specimen at the British Museum last year, and pointed it out to $\mathrm{Mr}$. Butler, that it had been overlcoked for so many years.

With regard to the localities given, viz. "Darjeeling (Lidderdale); between Nepal and Tibet" (Charlton), I must say a few words. Though more definite than the abominable expression "Northern India," which was and still is so much in favour among those ignorant of the physical geography of the Himalayas, or careless of the great importance of definite.

* As an instance of what may be accomplished in this direction by a painstaking and observant naturalist, I would commend to his notice Jordan's 'Diagnoses Plantarum' (1864), in which fifty-three species are described and twenty figured, most, if not all, of which are considered by other botanists to be varieties of Draba verna. 
localities particularly in that part of the world, they are still, in this case, misleading.

Darjiling is the central station and only town in British Sikkim, and is about twenty miles in a direct line from the plains, at an elevation of 7000 feet. It is the centre to which all native collectors bring their specimens for disposal ; and in this way most of the species found in British and Native Sikkim and the adjoining parts of Bhotan, Tibet, and Nepal, from the level of the plains up to 18,000 or 19,000 feet, are or will be labelled "Darjiling" ( $c f$. Proc. Zool. Soc. 1859, pp. 251-253), though they may come from districts belonging to two perfectly distinct zoological regions including three subregions - the Mongolian, the Himalo-Chinese, and the Indian ( $c f$. Elwes on the Geographical Distribution of Asiatic Birds, in P.Z.S. 1873, p. 657, and Hodgson, in Journ. As. Soc. Bengal, 1835). These divisions are most important, as, with some knowledge of their characteristics, many facts in distribution are easily explained which would otherwise be inexplicable. Dr. Lidderdale, so far as I am aware, never travelled in the interior of Sikkim, but, except one season at Buxa in Bhotan, spent his time at Darjiling and its immediate neighbourhood.

Argynnis gemmata is, with little doubt, a Palæarctic form most nearly allied to $A$.pales, and is an inhabitant of the higher, drier regions of the interior of Sikkim, near the Tibet frontier. I am nearly sure that I took it myself, in August 1870, near the Yakla Pass, at 13,000 feet elevation; but the specimen, with many more, was destroyed by damp. Two years ago I got it again from the late Mr. Mandelli, collected by a native in the same district; and, though it may straggle along the Chola range towards British Sikkim, I doubt its occurring below 10,000 feet. Its occurrence in Northeast Kumaon, for so one must, I suppose, interpret the vague term " between Nepal and Tibet" (though that term would equally well apply to native Sikkim if one had any reason to suppose that Charlton had ever been there), would then be perfectly natural and even to be expected; for though, in the case of birds, plants, and butterflies, the species found in the middle zone of elevation in Sikkim are mostly either peculiar or represented in the north-west Himalaya by allied forms, yet the alpine species are very often identical. The general terms Tibet and Chinese Tartary, so often given by writers as localities for species, should not be used if possible. Tibet is a country of enormous extent, of which only the frontier in two or three spots has been visited by naturalists, though Prejvalsky has recently penetrated the north-east for some 


\section{Mr. O. Thomas on a new Chinese Mole.}

distance. Nine times out of ten what is meant by these words is Ladak-a truly Tibetan province in its physical features, but politically part of Kashmir.

If, as we may hope, future travellers are able to penetrate or send native collectors into other parts of Tibet, such as the Chumbi valley, bordering on Sikkim, or the frontier districts adjoining Upper Assam, the locality from whence specimens are brought should always be specified, and the bare term Himalayas or, still worse, Northern India (which may mean any thing from Calcutta to Suddya or Kashgar) abolished.

As regards the next species described by Mr. Butler, Papilio nebulosus, I cannot agree with him, believing it to be merely an aberration of $P$. antiphates, as, indeed, he suggests it may be.

I procured at Darjiling two specimens of this aberration, neither of which agrees exactly with the other or with Mr. Butler's specimen in its markings, though they have both the same character. The gentleman in whose collection they were, and who, I believe, got them in the same season as Dr. Lidderdale's specimen, agreed with Mr. Godman and myself in this determination; and though it certainly appears to mimic $P$. euphrates, I think there is every reason to believe it is not a good species. If, however, it is necessary to breed it from the egg of $P$. antiphates in order to prove this, I am afraid many years will elapse before the matter is cleared up.

L.-Description of a new Species of Mole from China. By Oldfield Thomas, F.Z.S., British Museum.

The specimen here described was obtained near Pekin by the late Mr. Robert Swinhoe during the British expedition to that place in 1860. Shortly after its arrival in England it was mentioned by Dr. Gray* as a new species, but was not named or described. Later it was referred to by Mr. Swinhoe† under the belief that it was identical with a mole obtained by Père David in Mongolia, and described by Prof. A. MilneEdwards in his 'Recherches pour servir à l'Histoire naturelle des Mammifères' as Scaptochirus moschatusł. I propose to call the new species, on account of the comparative slenderness of its tail,

* P.Z. S. 1861, p. 390.

$\dagger$ P.Z.S. 1870, pp. 450 and 620. (In the latter place Mr. Swinhoe quotes the name as Scaptochirus Davidianus, a term which has never been used by Prof. Milne-Edwards.)

f Texte, p. 173, Atl. pl. 17 a. 


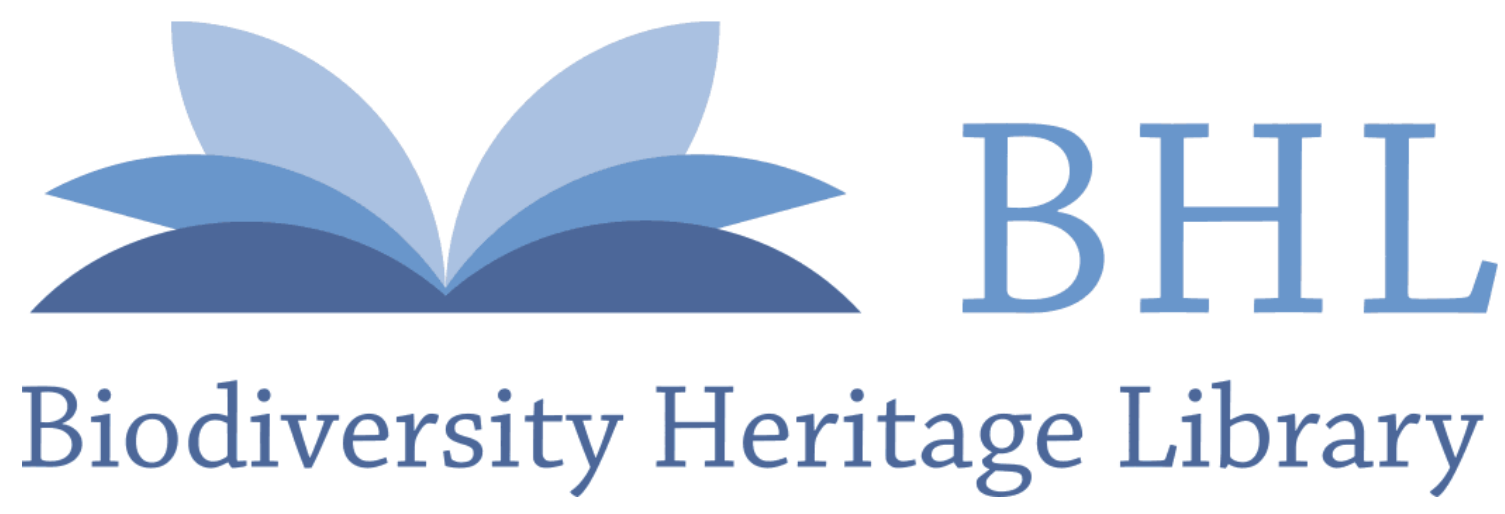

Elwes, Henry John. 1881. "XLIX.-Mr. Butler on butterflies from Japan." The Annals and magazine of natural history; zoology, botany, and geology 7, 464-469. https://doi.org/10.1080/00222938109459555.

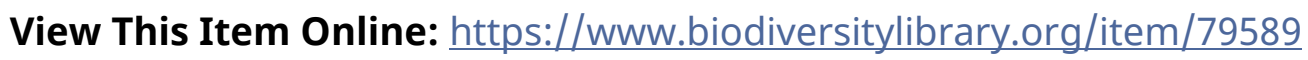

DOI: https://doi.org/10.1080/00222938109459555

Permalink: https://www.biodiversitylibrary.org/partpdf/62429

\section{Holding Institution}

Smithsonian Libraries

\section{Sponsored by}

Smithsonian

\section{Copyright \& Reuse}

Copyright Status: Public domain. The BHL considers that this work is no longer under copyright protection.

This document was created from content at the Biodiversity Heritage Library, the world's largest open access digital library for biodiversity literature and archives. Visit BHL at https://www.biodiversitylibrary.org. 